\title{
An Assessment of Occupational Health and Safety Regulations in Ghana: A Study of the Construction Industry
}

\author{
Alex Kojo Eyiah"1, Nongiba Alkanam Kheni2 ${ }^{*}$, Peter David Quartey ${ }^{3}$ \\ ${ }^{1}$ Department of Built Environment, Pentecost University College, Accra, Ghana \\ ${ }^{2}$ Department of Construction and Wood Technology Education, College of Technology Education of University of Education, \\ Winneba, Kumasi, Ghana \\ ${ }^{3}$ Nichona Construction Limited, Mamprobi-Accra, Accra, Ghana \\ Email: dreyiah@yahoo.com, ^kalkanam@yahoo.com, peterdavidq@yahoo.com
}

How to cite this paper: Eyiah, A.K., Kheni, N.A. and Quartey, P.D. (2019) An Assessment of Occupational Health and Safety Regulations in Ghana: A Study of the Construction Industry. Journal of Building Construction and Planning Research, 7, 11-31. https://doi.org/10.4236/jbcpr.2019.72002

Received: January 22, 2019

Accepted: May 11, 2019

Published: May 14, 2019

Copyright $\odot 2019$ by author(s) and Scientific Research Publishing Inc. This work is licensed under the Creative Commons Attribution International License (CC BY 4.0).

http://creativecommons.org/licenses/by/4.0/

\begin{abstract}
Occupational health and safety continues to be a major component of the built environment. The study investigates the effectiveness of occupational health and safety laws and regulations in the construction industry in Ghana and identifies the influencing factors. Face-to-face interviews were conducted among 49 stakeholders from four relevant groups-regulatory institutions, consultants, contractors, artisans and labourers. The findings of the study suggest that the existing occupational health and safety legal and regulatory framework is barely effective. Stakeholders were aware of the existence of some laws and regulations but mostly could not identify the specific laws and their relevant contents. Consequently, compliance is found to be irregular. The key recurring factors affecting effectiveness of occupational health and safety laws and regulations include: negligence and lack of priority for occupational health and safety, lack of training, lack of funds for occupational health and safety, lack of capacity of regulatory and supervisory institutions, and lack of occupational health and safety education within construction firms. The findings of the study are foundational in strategic interventions aimed at improving compliance with occupational health and safety laws and regulations in the construction industry of Ghana.
\end{abstract}

\section{Keywords}

Occupational Health and Safety Regulations, Institutions, Stakeholders, Construction, Ghana 


\section{Introduction}

The construction industry is reputed as being a hazardous environment due to the high rate of incidence of accidents and fatalities [1] [2] [3]. Construction is rated among the five most high risk sectors with solutions to occupational health and safety (OHS) issues proving invisible [4]. A study reported by [5] indicates that, in 2010/11 the construction industry accounted for $27 \%$ of fatal injuries to employees. This percentage rose to $38 \%$ out of the total fatal injuries to workers in 2017/2018. Asian and African countries have poorer occupational health and safety (OHS) performance compared with developed countries [6]. The difference in OHS performance is primarily due to lack of prioritization of OHS issues and perceived burden of having OHS measures in place [7]. Also, actions taken to mitigate risks of hazards on construction sites in developing countries are insufficient [8] [9] [10]. It can be argued that poor implementation of OHS standards in the construction industry will lead to frequent and more OHS incidents and accidents which could negatively impact on the progress of many projects. Indeed, the implementation of effective safety programmes and ensuring compliance with OHS regulations has been established as a critical success factor in construction projects [11]. An enabling OHS regulation forms the framework within which OHS programmes of construction firms when properly implemented will guarantee the success of construction projects.

Ghana's construction industry remains one of the key economic sectors in terms of its contribution to Gross Domestic Product (GDP) and employment. According to [12], there had been a steady increase in the sector's contribution to GDP with peak contribution of $13.7 \%$ in 2016 . Given the current growth trends, Ghana's construction sector will play a more pivotal role in socioeconomic development particularly when the country is projected to have a very high industrial growth of 19\% [13]. However, OHS injuries and accidents pose a significant threat to the projected industrial growth reported [14].

Previous studies suggest that legal and regulatory challenges among other factors contribute to low OHS performance in Ghana [15] [16] [17]. Whilst it is established that compliance with OHS laws and regulations in developing countries is weak, comprehensive studies on the effectiveness of OHS laws and regulations in these countries do not exist. For instance, [18] highlights the significance of the Ghanaian socio-cultural value systems, particularly, the extended family system and traditional religious value systems in OHS management within construction SMEs without consideration of the influence of prevailing regulatory systems. Other studies on OHS in developing countries as noted by [19] largely focus on the investigation of causes of accidents or the development of theoretical models to reduce accidents. Studies on OHS regulations are limited to few African countries such Nigeria and South Africa [16] [20].

The neglect of ex post assessment of OHS laws and regulation in Ghana means that the extent to which efforts to control the risk of hazards are driven by these laws and regulation as well as the performance of the regulatory institu- 
tions responsible for implementation is unexplored and remains unknown. For instance, in Ghana, while it is factually true that OHS laws and regulations are designed with the prime objective of eliminating hazards or controlling the risk of hazards in occupational settings (See Appendix 1), their effectiveness has never been tested against this objective. These concerns lead to a pertinent question; to what extent are OHS laws/regulations effective in addressing OHS issues in Ghana? In regard, the objectives of this study are to investigate the effectiveness of OHS laws/regulations in Ghana pertaining to the construction industry and identify the influential factors. The study will therefore contribute to formulating strategies to improve compliance as well as assist OHS regulators in the review of OHS regulations.

\section{Literature Review}

\subsection{The Role of Regulation in OHS Management}

Despite substantial investments made to mitigate OHS hazards in construction, accidents continue to occur with their attendant undesirable effects on workforce, equipment, and the environment [21] [22]. Available evidence suggests accidents in the construction industry are among the highest compared with other industries across countries [6] [23]. Globally, accidents in the construction industry are disproportionately higher than other industrial sectors. For instance, [5] reported average annual fatality rates of 1.77 whereas [24] estimate fatalities in the US construction industry as 23 per 100,000 workers. The underlying causes of accidents continue to prove elusive.

Regulation remains an essential means of setting standards for safe and healthy work environment for workers. However, such regulation differs markedly in terms of comprehensiveness, coverage, the extent of duties of stakeholders as well as their effectiveness across jurisdictions. Notably, OHS regulations are evolving from a much simpler form in the past to more complex ones to meet growing complexities of modern and industrialized workplaces [25]. However, the quest for zero accidents and ill health continue to be elusive task as it can be observed from the accident statistics already stated. One means of achieving increased OHS performance to business performance is through effective OHS regulations. After all obsolete and ineffective laws has been argued to result in undue bureaucracy, red tape procedures, difficulties in compliance and increased compliance cost [26] [27]. Therefore, this supports the need for research that evaluates OHS regulation as it forms the foundation for more effective regulation. Such a need is particularly strong in developing countries where OHS regulations are yet to be critically examined alongside growing industrialisation.

The thrust of the study by [26] is to draw cautionary measures on harmonization of regulations with specific reference to the harmonization of Australia's OHS laws due to problems in resolving individual differences and tendencies to overestimate the hamonisation's ability resolve such differences. Whereas the 
study by [27] sought to investigate designers' acceptance of their role in safe design in post-harmonized safety regulations of South Australia and concluded that harmonized regulations promoted safety related design requirements but on condition that in so doing the designers are protected from liability. Another study that providing us with insights on compliance of OHS regulation in relation to the management of OHS is the study by [28] in South China which examined the influence of workers' psychological climate on their health and safety awareness. Health and safety awareness is positively related to compliance of OHS regulations by workers on their psychological climate which in turn was found to be influenced by external and internal factors.

Although OHS regulations apply "across-the-board" in many countries, additional regulations exist in a few other countries to address specific sectors because of their unique characteristics. Construction is one such sector where because of multiple stakeholders and its hazardous nature. A typical example is the Construction (Design and Management) Regulations 2015 (CDM Regulations) implemented by European Union member countries. The responsibility of designers for OHS issues as stakeholders has been the subject of regulation and attention of researchers [27] [29] [30] [31] [32]. Appropriate regulations are necessary to guide designers on the one hand and on the other the enforcement of such regulations could bring desired change in designers attitude to OHS issues in construction as lax enforcement of OHS regulation has been shown to result in higher incidents of accidents [33] [34] [35].

The responsibility for OHS is a tripartite one involving governments, employers and employees [25]. Governments' solution to minimizing or arriving at zero accidents is primarily through institutional structures and OHS laws. The effect of OHS laws is to secure desired behaviour that will eliminate hazards or minimize their risk at the work place. In regard, employers as individuals or corporate entities are required to put in place adequate and appropriate measures to eliminate OHS hazards or minimize their risk. Employees on their part are expected to exercise their right to a safe and healthy working environment and by this, are responsible for their own safety. While the effect of regulation is a desired behaviour change that will result in safe and healthy work environment the ultimate outcome is the non-occurrence of accidents. A collaborative approach to managing OHS through safety committees with employee participation (employees could be union representatives) as part of employers' OHS management policy has been shown to result in high OHS performance.

\subsection{OHS Administration in Ghana}

The activities of many organizations both public and private directly or indirectly affect the development of the construction industry. According to [36], public institutions may interact directly with the industry by regulating its activities or acting on behalf of government as financiers, suppliers, regulators, clients, or paymasters. Non-governmental organizations including professional institutions, research institutions, private educational institutions, trade unions, 
employers' organization, private clients, and donor agencies significantly influence the activities of the construction industry [18]. The Ministry of Roads and Transport (MRT) and the Ministry of Water Resources, Works and Housing (MWRWH) have direct responsibility for the overseeing and implementing state policy in relation to the construction industry. The latter is responsible for the building construction industry, and together with other ministries, departments and agencies are mandated to ensure that every building project satisfies relevant legal requirements including planning and building regulation. For instance, the Ministry of Manpower Development and Employment (MMDE) through its Labour Department responsible for employment and labour issues. Its Factory Inspectorate and the Occupational Health Unit of the Ministry of Health are responsible for occupational health and safety issues.

The general occupational $\mathrm{H} \& \mathrm{~S}$ legal and regulatory environment includes a fragmented local and international laws and conventions. Locally, the study by [18] identifies three laws: 1) Factories, Offices, and Shops Act 1970 (Act 328), 2) Workmen's Compensation Act, 1987 (PNDCL 187), 3) Labour Act, 2003 (Act 651), and 4) Ghana Health Service and Teaching Hospitals, 1996 (Act 526). The Factories, Offices, and Shops Act 1970 (Act 328) is supported by three regulations made under the repealed Factories Ordinance 1952, which are: Factories (Woodworking) Regulations, 1959; Food Factories (Welfare) Regulations, 1959; Factories (Docks Safety) Regulations, 1960. International labour organization (ILO) conventions relating to occupational health and safety ratified by Ghana include: Underground Work (Women) Convention 1935 (No. 45); Labour Inspection Convention 1947; Radiation Protection Convention 1960 (No. 115); Guarding of Machinery Convention 1963 (No. 119); Hygiene (Commerce and Offices) Convention 1964; and, Working Environment (Air Pollution, Noise and Vibration) Convention, 1977. One of the shortcomings of the OHS legal framework is that it is fragmented [18]. There is also the lack of policy that clearly defines the rights and responsibilities of stakeholders including government, employers and employees [37]. The study by [37] further attributed the fragmentation of OHS laws to the inability of OHS statutes to evolve taking account of existing laws and regulations and resulting in overlapping areas of jurisdiction.

\subsection{The Effectiveness of OHS Regulation}

Regulation refers to laws or rules that have their origin in the legislative arm of government which seek to effectively manage OHS issues that negatively impact on persons whether employed or not. According to [38], the effectiveness of regulations must consider the regulations, implementing organisations and other organisations or individuals whose behaviour the regulations seek to regulate. The consequence of effective implementation and enforcement of OHS regulations is desirable behavioural changes in regulated organizations which will lead to desired intermediate outcomes and ultimately, reduced accident rates in regulated organisations or occupations covered by the regulation (See Figure 1). 
Based on the above model, the impact or effectiveness of OHS regulation refers to the extent to which regulation is able to bring about change in targeted behaviour within occupations or lead to improvements in conditions in occupations. Inferred from this explanation, the effectiveness of OHS regulations covers the activities of regulatory institutions, behaviour changes of organisations and outcomes both intermediary and ultimate. The effectiveness of OHS regulation is influenced by indicators that cover the stated areas of and response to OHS regulation. The indicators effectively and discretely measure activities of regulatory institutions, compliance behaviour of construction companies and OHS outcomes on construction projects. Table 1 presents a summary of indicators that cover these areas.

\section{Methods}

A qualitative research design based on interpretive research philosophy was adopted to investigate the effectiveness of the OHS laws/regulations and the underlying factors affecting regulatory effectiveness on building construction sites in Ghana. Interpretivist approach relies on research subjects meanings they ascribe to phenomena or social constructs that form the tenets of their understanding. It is therefore commonly used to understand people's experiences and to express their perspectives [40]. In this study, the interpretivist approach enabled understanding of the social implications of the phenomenon (OHS regulation) whilst allowing insights to be gained through socially constructed knowledge of the interview participants [41] [42] [43] [44].

The study relied on primary data obtained through face-to-face semi-structured interviews [45] conducted with 49 participants, each belonging to at least one of five stakeholder groups; regulators, consultants, contractors, artisans and labourers. Data saturation was the guiding principle in limiting the number of

\begin{tabular}{|c|c|c|c|c|c|}
\hline $\begin{array}{l}\text { Regulatory } \\
\text { Institution }\end{array}$ & $\rightarrow \begin{array}{l}\text { OHS } \\
\text { Regulation }\end{array}$ & $\begin{array}{l}\text { Implementation \& } \\
\text { enforcement }\end{array}$ & $\begin{array}{l}\text { Behavioural } \\
\text { Change }\end{array}$ & $\rightarrow \begin{array}{l}\text { Intermediate } \\
\text { outcomes }\end{array}$ & $\begin{array}{l}\text { Ultimate } \\
\text { outcomes }\end{array}$ \\
\hline
\end{tabular}

Source: Adapted from [39].

Figure 1. Causal map and effects of regulation.

Table 1. Indicators of effectiveness of OHS regulations.

\begin{tabular}{|c|c|c|c|}
\hline $\begin{array}{l}\text { Activities of regulatory } \\
\text { institutions }\end{array}$ & $\begin{array}{c}\text { Behaviours of construction firms } \\
\text { and Project parties }\end{array}$ & Intermediary OHS outcomes & Ultimate OHS outcomes \\
\hline $\begin{array}{l}\text { - Education aimed at creating } \\
\text { - Compliance inspections } \\
\text { - Mandatory registration of } \\
\text { construction sites } \\
\text { - Penalties for non-compliance } \\
\text { - Resources available to institution }\end{array}$ & $\begin{array}{l}\text { - Compliance measures. } \\
\text { - Health and safety procedures on } \\
\text { construction sites. } \\
\text { - Incorporation of OHS laws into } \\
\text { contract conditions. } \\
\text { - OHS manuals developed and in } \\
\text { conformity with OHS regulations. } \\
\text { - Resources to facilitate compliances. }\end{array}$ & $\begin{array}{l}\text { - Amelioration of underlying OHS } \\
\text { problems \& positive changes in } \\
\text { conditions. } \\
\text { - Awareness level of OHS Employees } \\
\text { - Reduced lost time due to accidents. } \\
\text { - More OHS inductions \& training }\end{array}$ & $\begin{array}{l}\text { - Amelioration of underlying } \\
\text { OHS problems \& positive } \\
\text { changes in conditions. } \\
\text { - Decreased accident/injury } \\
\text { rates } \\
\text { - Cost incurred in } \\
\text { compliance }\end{array}$ \\
\hline
\end{tabular}

Source: Adapted from [39]. 
study participants to 49. Data saturation used in this sense refers to a point at which new or additional yielded by the interviews provided no insights regarding the research questions posed [46] cited by Saunders et al. [47]. This means that the number of interviews progressed up to a point where no additional/new insights on the research objectives were obtained from the study participants. Further interviews were therefore unnecessary as they were thought by the researchers to yield no additional insights to enable the research objectives to be achieved. The selection of the interview participants involved a blend of heterogeneity sampling and quota sampling (both are different kinds of purposive sampling) because of the need to consider the varied views of stakeholders and to ensure their views were fairly reflected by the study. Additionally, the selection criteria were; experience in the construction industry and knowledge in OHS matters.

The main analytical tool is framework analysis [48] [49] which is a qualitative method that is aptly suited for applied policy research [50]. According to [50], framework analysis provides an excellent tool for the assessment of policies and procedures from the viewpoint of the very people that they affect. Data analysis involved five stages: familiarization; identifying a thematic framework; indexing; charting; and mapping and interpretation [51]. The process of developing a thematic framework involves coding which are based on the indicators presented in Table 1 in the preceding section.

\section{Results}

\subsection{Behaviour of Regulatory Institutions}

Many institutions are responsible for OHS in Ghana. In assessing the effectiveness of regulatory activities, the Factories Inspectorate Department, Labour Department, and consultants were considered. Enforcement of respective laws contract clauses on OHS under the jurisdiction of the stated institutions is not uniform as can be inferred from participants' views. Labour officers were of the view that they issued labour certificates to construction firms with good employee relations. For instance, one labour officer said:

I can say that the department has been issuing labour certificates to contractors with good history of labour relations and the number of such certificates issued continues to increase over the years. (Labour Officer)

Other activities carried out by the labour officers include; health, safety and welfare education of contractor associations and settlement of labour disputes that occur in construction companies. In this regard one labour officer remarked on the achievements of the department as follows:

We carry out health and safety awareness campaigns for contractors who belong to the Association of Road Contractors, Ghana and the Association of Building and Civil Engineering Contractors of Ghana. We educate them on laws governing labour standards and occasionally, where dispute arise we step in to settle them. (Labour Officer) 
On the contrary, Factory Officers failed to carry out activities that relate to their responsibilities under Factories, Offices and Shops Act 1970, (Act 328). It was apparent that the department is severely constrained due to inadequate logistics and skilled factories inspectors. A senior Factory Inspector remarked thus:

Our staff turnover is high partly because the employment contract is not attractive. We recruit staff, get them trained for the basic rudiments of factory inspection and then after a year or two, they find some lucrative places to go and work. We are also constrained in terms of transport and modern equipment to carry out OHS surveys and inspections. (Factory Officer)

Although the department is mandated to carry out workplace surveys, provide OHS information, register factories including construction sites and proactively promote OHS, these activities were not carried out in the construction sector. It however, appears that the department responds to major incidents, not swiftly though.

We investigate major accidents when they are brought to our notice against the constraints of lack of adequate resources. We are hoping for revamp of our equipment because many of them are not properly functioning. (Factory Officer).

Consultants supervise construction projects, ensuring that contract clauses, particularly those relating to OHS are complied with by contractors. The extent of incorporation of OHS laws into construction contracts in Ghana was however observed to be very basic and only clauses relating first aid, welfare as well as those that sought to indemnify the client from damages and compensations of injured workers are often included in the bills of quantities.

On moral grounds, consultants have commitment to ensure OHS standards are maintained on construction sites, particularly those prescribed by OHS laws. However, incorporation of these laws into conditions of contract is scanty and I am afraid, we are not pace setters this wise. Often, we ignore the need for safety provisions in both design and construction phases perhaps because there are no explicit provisions in the law to do so (Consultant).

The Consultants mentioned the Contractors All-Risk (CAR) Insurance as an essential contract provision although it is rather an insurance policy than a law. The consultants interviewed expressed that contract clauses relating to OHS need to be more detailed so as to relieve the contractor of the burden of compliance. Clients have responsibility for OHS matters affecting their projects. However, the main OHS laws in Ghana are not quite explicit on the responsibility of clients. One consultant noted that:

When contract clauses fail to properly address OHS issues, it is highly likely that the contractor becomes overburden with having to comply with OHS laws. Of course, clients will like to distance themselves from OHS risk. There is then the need to transfer such risk through effective and adequate stipulations of contract clauses. (Consultant)

One consultant indicated that she undertakes professional indemnity insurance in respect of her liability should accidents occur as a result of failure to 
adequately address OHS issues at the design phase.

\subsection{Compliance Behaviour of Construction Companies}

Construction companies were observed to be fully aware of the existence of some OHS laws and regulations. The interview participants were aware about the Labour Act, 2003 and Workmen's Compensation Law 1987 and took necessary actions to comply with these laws that were incorporated into contract clauses. However, it was observed that the level of awareness among the participants with respect to the main OHS law (Factories, Offices and Shops Act, 1970) was unexpectedly low. Artisans were generally aware of OHS laws and regulations though the specific contents of the laws were not fully understand by them. Labourers on the other hand held the view that the management of OHS risks was the responsibility of their employers and were not generally involved in OHS management of construction sites.

Notably, contractors (top management of firms) take little consideration of the cost of safety and instead tend to, as much as available resources permit, to implement health and safety standards on construction sites in accordance to provisions in contract clauses. Implementing measures beyond those required in contract clauses in compliance with the provisions OHS laws is see as 'going an extra mile' with little motivation either by punitive measures in OHS laws or optimising the cost of safety (cost of OHS measures weighed against the cost of accidents and ill health). This is seen from the quotation below:

The baseline is complying with all health and safety provisions in contracts but much needs to be done by going an extra mile by complying with main OHS laws of Ghana or ILO Conventions which unfortunately are often not implemented because of certain constraints contractors face. (Manager of Construction Company

While the above quotation may be indicative of the of the lax enforcement regime by regulatory institutions, it is suggestive that construction companies are a long away of adopting voluntary compliance of OHS standards on construction sites. This is particularly so probably because of a lack of the appreciation of cost savings arising from effectively managing OHS and an industry milieu in which OHS is given little attention, particularly through OHS awareness campaigns incentives for compliance with OHS laws as part of contractor selection.

A key factor debilitating compliance behaviour is the absence of specific construction OHS laws. The participants pointed out the existence of at least three laws that governed $\mathrm{H} \& \mathrm{~S}$ in general but not building construction to be specific. These general laws are the Factories, Offices and Shops Act, 1970 (Act 328), Labour Act, 2003 (Act 651), and Workmen's Compensation Act, 1987 (PNDC 187). Specific standards that are applicable to construction works spelt out in these laws were unclear to these study participants. Also, the nature of the risk of hazards expected on construction works is detailed out in OHS laws to facilitate effective health and safety planning. Regular training of contractors on OHS matters affecting construction works is lacking although the study participants 
acknowledged the Association of Road Contractors of Ghana (ASROC) have organised workshops with OHS as part of the content.

Artisans and labourers are much aware of the need to take precautionary measures including wearing personal protective equipment (PPE) such as hard hats, safety boots, eye goggles, face mask and protecting designed for their respective works. However, they could not mention the technical requirements associated with these PPEs and the specific laws and regulations that make their use mandatory. Regarding their use of PPEs, participants indicated that their use was irregular. The reasons are summarized below:

In instances were safety equipment are provided some workers use them wrongly because they do not know how to use them properly. Others do not use them at all because of ignorance or the fact that the safety equipment does not fit the worker or they do not appreciate the level of risk involved in the job being executed by them. Some also feel they retard their progress of work. (Labourer)

\subsection{Factors Affecting the Effectiveness of OHS Regulations}

Figure 2 reveals 13 major factors affecting the effectiveness of OHS laws in the building construction industry. The seven most recurring theme is the management negligence and lack of priority for OHS, lack of training, lack of funds for OHS, lack of investment in OHS management, lack of capacity of regulatory and supervisory institutions, lack of OHS education within construction firms, and OHS considered unimportant. Little reference is made to the high cost of implementing OHS practices, lazy and negligent attitudes of workers, the belief that compliance with OHS slows productivity and negative incentive created by the

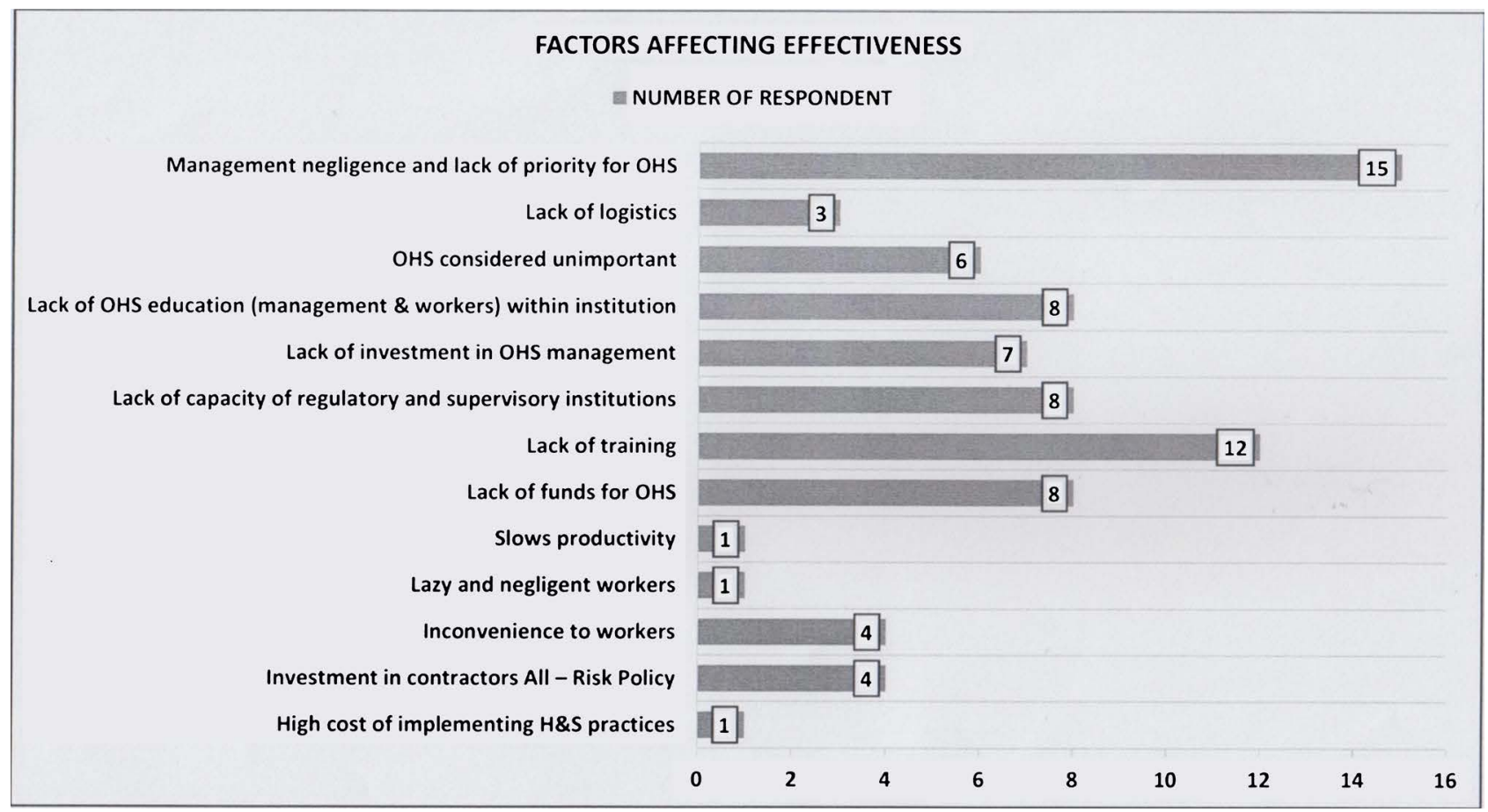

Figure 2. Factors affecting the effectiveness of OHS laws and regulations. 
investment in Contractors All-Risk Policies.

The factors affecting the effectiveness of OHS laws and regulations cover the major stakeholders in OHS matters in Ghana namely; construction firms, regulatory institutions, consultants and construction site workers. Some management of construction firms consider OHS unimportant and costly and therefore do not allocate adequate funds in their effort at investing in OHS management, particularly in OHS education, training and the provision and maintenance of the needed logistics. The lack of capacity of regulatory institutions in relation to enforcement OHS laws militate against the effectiveness of OHS administration. The implementation of measures aimed at enhancing OHS performance is necessary notwithstanding the lack of OHS laws that are specifically for the construction industry of Ghana. In terms of fostering the implementation of OHS standards on construction sites, artisans and labourers may not play their role and this leaves a gap in workers' participation in OHS management within construction firms. The lack of participation and interest in OHS matters by workers negatively affects the implementation of OHS laws and regulations as well job tenure and security.

\section{Discussion}

The section presents the discussion of results in relation to the three themes in the study namely; the patterns of behaviour of regulatory institutions and consultants, actions of construction companies and factors affecting the effectiveness of OHS regulations and laws.

\subsection{Regulatory Institutions and Consultants}

The implementation of health and safety standards on construction sites may be obtained through regulatory enforcement or voluntary compliance or a combination enforcement regime and voluntary compliance. The thrust of regulatory institutions is to enforce OHS laws and ILO conventions relating to OHS this arguably is associated with propensity to make OHS related improvements within regulated organisations [18] [52]. Guided by the premise that the effectiveness of OHS laws and regulations is a function of the content of the laws and regulations, the actions of implementing organisations and other organisations or individuals whose behaviour the regulations seek to regulate in line with the study by [38] definition of regulatory effectiveness, the activities of regulatory institutions responsible for the Labour Law, Act 2003, the Workmen's Compensation Law 1987 and the Factories, Offices and Shops Act 1970 were assessed. Enforcement activity in respect of OHS matters is observed to be largely based on major incidences or accidents whether reported or not. Beyond the requirement to report such incidences regulatory institutions are generally required to ensure compliance with OHS laws although the extent to which this is achieved is found to be poor and dependent on the particular or its implementing institution as observed in this study. Lack of capacity to effectively implement OHS 
laws is due to factors such as lack of adequate budgetary allocations for enforcement activity, insufficient logistics available to regulatory institutions, human resource constraints and the particular characteristic of the construction industry (projects being transient and visibility of project sites not so apparent or easily accessible). Ineffective enforcement by regulatory institutions results in lack of fear for punitive measures for flouting OHS regulations and laws and consequently low level of compliance with OHS laws and regulations. Conversely, as noted by [53], a key factor moving proactive OHS management is fear of prosecution or punitive measures by maintaining an image of responsibility.

Consultants play an important role in ensuring OHS standards contained OHS laws and regulations are complied with and often incorporate clauses in contracts to address the requirements stipulated in OHS laws and regulations. However, a problem does arise regarding the sufficiency of contract clauses in addressing OHS laws and regulations. Observed in the present paper, contract conditions are often not sufficiently detailed on specific health and safety issues such as temporary works and the management of health and safety risks. Whilst, standard forms of contracts make provisions regarding the management of health and safety risk, not all projects involve their use; this is particularly true of informal construction [14]. Lead consultants' influence on OHS standards is limited to projects they design, and procured by traditional procurement process. Given that no regulation exist, presently in Ghana that directly places the responsibility for OHS on the shoulders of designers, they are guided by building regulations and the duty of care they owe to the client as relates to OHS in traditionally procured projects. Designers are wary of the sense of protection that the procurement method offers them and this, in part, is in accord with the findings of the study by [27] that designers perceived harmonized regulations as promoting safety related design requirements but on condition that in so doing the designers are protected from liability. However, these observations are limited to formal construction processes followed through for public sector projects. In contrast, informal construction in Ghana does not involve the use of expertise of consultants and neither mandatory to use or involve the use of standard forms of contracts in the procurement process.

\subsection{Compliance with OHS Regulations by Construction Companies}

As employers, construction companies' responsibility for OHS is mandatory. Whilst literature suggests a gradual shift from regulatory regime to voluntary compliance in developed nations [54], developing countries are far behind this shift in paradigm in OHS management. Not surprisingly, as observed in this study, voluntary compliance is minimal and much effort made in managing OHS is rather to comply first with contract provisions on health and safety and second an attempt at complying with OHS laws and regulations. An exception to this position exist in the case of contracts procured through international tenders where domestic construction firms may work as subcontractors and would 
have to, in addition conform to OHS cultures of foreign contractors and OHS laws of donor countries. Whilst working as subcontractors under foreign contractors may be an incentive for voluntary compliance, the gains by way of experience in OHS management will only be lasting for such contractors if there is similar job continuity. These results confirm the low to moderate commitment to OHS management by management of construction companies. Apparently, budgetary allocations for OHS management are woefully inadequate, trainings in OHS for site level staff are sparingly carried out and procurement and maintenance of PPEs are unplanned and irregular. Undoubtedly, such a situation is worrisome as many authors on OHS best practices have since documented the importance of top management commitment in improving health and safety performance [55] [56] [57] [58].

Construction managers' belief that it is necessary and morally right to comply with OHS regulations as well as a genuine desire to improve staff morale and productivity is a contributory factor to proactive OHS management [53], the results of the study suggest that management of construction companies tend to accord OHS low priority in comparison with profits and compliance with OHS laws and regulations is invariably limited to compliance with contract provisions on OHS means there is little evidence to support proactive OHS behaviour or management on the part of management. Similarly, worker involvement in OHS management was observed by study participants to be rarely considered although the participants acknowledged existence of unionized bodies in their organisations. Workers, especially site managers and union representatives lacked empowerment on OHS issues and this could adversely affect compliance with OHS laws and regulations and the achievement of safe and healthy construction sites.

The results of the study suggest artisans and labourers on construction sites are much aware of the need to take precautionary measures including wearing PPEs such as hard hats, safety harness, safety boots, hand glovers etc. This result is consistent with the findings of [59]. However, there is apparent lack of adequate understanding on the use and maintenance of PPEs as well as the specific laws and regulations that sanctioned their use. Although site operatives are generally aware of hazards on construction sites and the need to take precautionary measures, reporting on hazards that pose eminent danger or high risk to site management staff is only done when workers feel assured of their job security. Apart from the pressure of job security other forms social influences exist which may be brought to bear on workers and thus affect their psychological climate and consequently health and safety awareness level [28]. The results suggest urgent need to improve OHS communication and involvement of site operations in OHS management activities such as OHS meetings, risk assessments and dissemination of OHS information. A plausible cause of the poor communication may be attributed to lack of a structured approach to the implementation of OHS communication within the firms studied in contrast with rather structured communication strategies that have been observed to result in reduction in inci- 
dent rates and cost saving measures [19].

\subsection{Factors Affecting the Effectiveness of OHS Laws and Regulations}

The factors that have contributed to the ineffective OHS legal and regulatory environment are many and are categorized into three namely; employer-related factors, employee-related factors and institutional factors. Employer-related factors comprised eight factors namely; management commitment, lack of funds for OHS implementation, lack of investment, logistical constraints, OHS education and training, cost of implementing OHS practices and investment in contractors' all-risk policy. As much as employees are often not insured against the risks and accidents identified above, investment in insurance such as the Contractors' all-risk policy, which is a required for some project particular those related to the government, may have created a negative incentive to reduce investment in $\mathrm{H} \& \mathrm{~S}$. It emerged from the study that contractors and consultants who represent clients tend to consider investment in the contractors' all-risk policy as an alternative to investment in H\&S, instead of viewing it as complementary. This may have contributed to the low investment in $\mathrm{H} \& \mathrm{~S}$ education, training and logistics.

At the employee level, five factors were identified as affecting the effectiveness of the OHS legal and regulatory framework. These include; OHS practices being an inconvenience to workers, compliance with OHS procedures slowing productivity, lack of training, lack of education, lazy and negligent attitude of worker. It is interesting to find that workers may find OHS procedures as an inconvenience probably because such workers prefer to cut corners or 'shortcuts'. It is quite understandable though because most may have worked for so many years without them. Use of PPEs may even be inconvenient to workers either due to discomfort when wearing them or because the design of particular PPEs is not well-tailored to their physiological characteristics or simply because of first time of use of such PPEs. Hence, workers may find it uncomfortable using PPEs such as hard hats, protective clothing, safety boots, safety harness, hand gloves and eye goggles. With time and gradual use, workers can become used to the stated PPEs.

Stakeholders believe that the lack of adequate capacity of a regulatory and supervisory institutions responsible for implementation OHS laws and standards adversely affect the effectiveness of the existing legal and regulatory framework. One plausible reason may the fragmentation of OHS laws and multiple institutions responsible for their implementation. OHS Laws lack specific standards and there exist no guidance manuals as well as the absence of specific OHS laws and regulations for the construction industry. Besides the need to review and consolidate the laws, stakeholders believe that the need to create efficient enforcement mechanisms remain the biggest challenge. Professional associations and industry groups like the Chartered Institute of Building, Association of Building and Civil Engineering Contractors of Ghana, Association of Road Con- 
tractors of Ghana, Ghana Institute of Construction and the Ghana Real Estate Development Association exist but membership is voluntary; consequently, most building contractors are not members and construction firms operate outside the sphere professional influence which may not enabling environment for compliance of OHS laws and regulations.

\section{Conclusions}

The findings of the study suggest a lack of capacity of OHS institutional environment to effectively implement OHS laws and regulations. Also, not surprisingly, compliance behaviour of construction companies is undesirably low confirming the OHS laws and regulations have little impact in securing OHS standards on construction sites. The study unravels some recurring factors that influence the effectiveness of OHS laws and regulations to include: negligence and lack of priority for OHS, lack of training, lack of funds for OHS, lack of investment in OHS management, lack of capacity of regulatory and supervisory institutions, lack of OHS education within construction firms, and OHS considered unimportant. The findings of the study are foundational in developing strategic interventions aimed at improving compliance with OHS laws and regulations in the construction industry in Ghana.

Limitations of the study include lack of general applicability of the findings to the construction industry of Ghana due to the purposefully selected sample of 49 participants involved in construction projects in the capital city of Ghana, Accra. Future research on survey of the construction industry of Ghana with objectives similar to the present study is recommended to validate the stated findings. Notwithstanding the limitations of the study, the findings have implications for OHS policy makers and OHS decision-making within construction firms.

\section{Acknowledgements}

The authors will like to thank the Association Building and Civil Engineering Contractors of Ghana (ABCECG) for supporting the project. We also will like to express our profound gratitude to the managing directors of the construction companies that participated in this study and also granted access to their construction project sites.

\section{Conflicts of Interest}

The authors declare no conflicts of interest regarding the publication of this paper.

\section{References}

[1] Smallwood, J., Haupt, T. and Shakantu (2008) Construction Health and Safety in South Africa: Status and Recommendations. CIDB Report.

[2] Chi, S. and Han, S. (2013) Analyses of Systems Theory for Construction Accident Prevention with Specific Reference to OSHA Accident Reports. International Jour- 
nal of Project Management, 31, 1027-1041.

https://doi.org/10.1016/j.ijproman.2012.12.004

[3] Jokkaw, N. and Tongthong, T. (2016) Factors Influencing on Safety Management Status and Evaluation of Safety Management Status in Construction Projects in Cambodia. ASEAN Engineering Journal Part C, 5, 34-48.

[4] International Labour Organization (2013) Safety and Health at Work: Hopes and Challenges in Development Cooperation. International Labour Organization Geneva, Geneva.

[5] Health and Safety Executive (HSE) (2018) Workplace Fatalities in Great Britain 2018. HSE, Annual Statistics, July 4, 2018.

http://www.hse.gov.uk/statistics/pdf/fatalinjuries.pdf

[6] Hämäläinen, P., Takala, J. and Kiat, T.B. (2017) Global Estimates of Occupational Accidents and Work-Related Illnesses 2017. Workplace Safety and Health Institute, Ministry of Manpower Services Centre, Singapore.

http://www.icohweb.org/site/images/news/pdf/Report\%20Global\%20Estimates\%20 of\%20Occupational\%20Accidents\%20and\%20Work

[7] Arum, C. and Aigbavboa, C. (2018) Assessment of Health and Safety Compliance in the Nigerian Construction Industry. Proceedings of the Joint CIB W099 and TG59 Conference Coping with the Complexity of Safety, Health, and Wellbeing in Construction Salvador, Salvador, 1-3 August 2018, 121-129.

[8] Othman, A.A.E. (2012) A Study of the Causes and Effects of Contractors' Non-Compliance with the Health and Safety Regulations in the South African Construction Industry. Architectural Engineering and Design Management, 8, 180-191. https://doi.org/10.1080/17452007.2012.683242

[9] Gibb, A.G.F. and Bust, P. (2006) Construction Health and Safety in Developing Countries. European Construction Institute, Loughborough.

[10] Haupt, T. and Smallwood, J. (1999) Health and Safety Practices on Community Projects: The South African Experience. In: Singh, A., Hinze, J. and Coble, R.J., Eds., Proceedings of the Second International Conference of CIB Working Commission W99, A.A. Balkema, Rotterdam Brookfield, Honolulu, 47-54.

[11] Al-Kuwaiti, E., Ajmal, M.M. and Hussain, M. (2017) Determining Success Factors in Abu Dhabi Health Care Construction Projects: Customer and Contractor Perspectives. International Journal of Construction Management, 18, 430-445. https://doi.org/10.1080/15623599.2017.1333401

[12] Ghana Statistical Service (GSS) (2017) Statistics for Development and Progress: Provisional 2016 Annual Gross Domestic Product. April 2017 Edition, 5. http://www2.statsghana.gov.gh/docfiles/GDP/GDP2017/April/Annual_2016_GDP_ April\%202017_Edition.pdf

[13] Filmer, D. and Fox, L. (2014) Youth Employment in Sub-Saharan Africa. Africa Development Series. World Bank, Washington DC.

https://doi.org/10.1596/978-1-4648-0107-5

[14] Kheni, N.A., Adzraku, W.D. and Boateng, C. (2018) Improving Health and Safety Performance in Low- and Lower-Middle-Income Countries: The Role of Site Managers in Ghana. Journal of Construction, 1, 14-24.

[15] Kheni, N.A., Gibb, A.G.F. and Dainty, A.R.J. (2010) Health and Safety Management within SMEs in Developing Countries: A Study of Contextual Influences. Journal of Construction Engineering and Management, 136, 1104-1115. https://doi.org/10.1061/(ASCE)CO.1943-7862.0000218 
[16] Windapo, A. and Oladapo, A. (2012) Determinants of Construction Firms' Compliance with Health and Safety Regulations in South Africa. 28th Annual ARCOM Conference, Edinburgh, 3-5 September 2012, 433-444.

[17] Ofori, G., Owusu-Manu, D., Adesi, M. and Donkor-Hyiaman, K.A. (2014) Study on Regulatory Agency for Construction Industry in Ghana. A Baseline Study Commissioned by the Chartered Institute of Building-Ghana and Funded by the World Bank Business Sector Advocacy Challenge Fund.

[18] Kheni, N.A. (2008) Impact of Health and Safety Management on Safety Performance of Small and Medium-Sized Construction Businesses in Ghana. Unpublished PhD Thesis, Department of Civil Engineering, Loughborough University, Loughborough.

[19] Siew, R.Y.J. (2015) Health and Safety Communication Strategy in a Malaysian Construction Company: A Case Study. International Journal of Construction Management, 15, 310-320. https://doi.org/10.1080/15623599.2015.1084469

[20] Windapo, A., Umeokafor, N.I. and Olatunki, O.A. (2018) Self-Regulation amongst South African Contractors in Achieving Legislative Requirements on Occupational Health and Safety. Proceedings of the Joint CIB W099 and TG59 Conference Coping with the Complexity of Safety, Health, and Wellbeing in Construction Salvador, Salvador, 1-3 August 2018, 187-196.

[21] Cagno, E., Micheli, G.J.L., Jacinto, C. and Masi, D. (2014) An Interpretive Model of Occupational Safety Performance for Small- and Medium-Sized Enterprises. International Journal of Industrial Ergonomics, 44, 60-74. https://doi.org/10.1016/j.ergon.2013.08.005

[22] Ramli, A.A., Watada, J. and Pedrycz, W. (2011) Possibilistic Regression Analysis of Influential Factors for Occupational Health and Safety Management Systems. Safety Science, 49, 1110-1117. https://doi.org/10.1109/FUZZY.2010.5584407

[23] International Labour Organisation (ILO) (2017) General Survey on the Occupational Safety and Health Instruments Concerning the Promotional Framework, Construction, Mines and Agriculture. In: 106th Session International Labour Conference, International Labour Office, Geneva, Report III (Part 1B).

[24] Dong, X.S., Largay, J.A. and Wang, X. (2014) New Trends in Fatalities among Construction Workers. CPWR Data Brief, 3, 1-10. https://www.cpwr.com/sites/default/files/publications/Data\%20Brief-\%20New\%20T rends\%20in\%20Fatalities\%20among\%20Construction\%20Workers.pdf

[25] Alli, B.O. (2008) Fundamental Principles of Occupational Health and Safety. 2nd Edition, International Labour Office, Geneva.

[26] Windholz, E. and Hodge, G. (2012) The Magic of Harmonisation: A Case Study of Occupational Health and Safety in Australia. Asia Pacific Journal of Public Administration, 34, 137-155. https://doi.org/10.1080/23276665.2012.10779391

[27] Bong, S., Rameezdeen, R., Zuo, J., Li, R.Y.M. and Ye, G. (2015) The Designer's Role in Workplace Health and Safety in the Construction Industry: Postharmonized Regulations in South Australia. International Journal of Construction Management, 15, 276-287. https://doi.org/10.1080/15623599.2015.1094850

[28] Fung, I.W.H., Tam, V.W.Y., Sing, C.P., Tang, K.K.W. and Ogunlana, S.O. (2016) Psychological Climate in Occupational Safety and Health: The Safety Awareness of Construction Workers in South China. International Journal of Construction Management, 16, 315-325. https://doi.org/10.1080/15623599.2016.1146114

[29] Gambatese, J.A., Behm, M. and Rajendran, S. (2008) Design's Role in Construction Accident Causality and Prevention: Perspectives from an Expert Panel. Safety Sci- 
ence, 46, 675-691. https://doi.org/10.1016/j.ssci.2007.06.010

[30] Öney-Yazici, E. and Dulaimi, M.F. (2015) Understanding Designing for Construction Safety: The Interaction between Confidence and Attitude of Designers and Safety Culture. Architectural Engineering and Design Management, 11, 325-337. https://doi.org/10.1080/17452007.2014.895697

[31] Sacks, R., Whyte, J., Swissa, D., Raviv, G., Zhou, W. and Shapira, A. (2015) Safety by Design: Dialogues between Designers and Builders Using Virtual Reality. Construction Management and Economics, 33, 55-72. https://doi.org/10.1080/01446193.2015.1029504

[32] Manu, P., Poghosyan, A., Agyei, G., Mahamadu, A. and Dziekonski, K. (2018) Design for Safety in Construction in Sub-Saharan Africa: A Study of Architects in Ghana. International Journal of Construction Management, 21, 1-13.

https://doi.org/10.1080/15623599.2018.1541704

[33] Gervais, M. (2003) Good Management Practice as a Means of Preventing Back Disorders in the Construction Sector. Safety Science, 41, 77-88.

https://doi.org/10.1016/S0925-7535(01)00070-4

[34] Goldenhar, L.M., Moranb, S.K. and Colligan, M. (2001) Health and Safety Training in a Sample of Open-Shop Construction Companies. Journal of Safety Research, 32, 237-252. https://doi.org/10.1016/S0022-4375(01)00045-7

[35] McCann, M. (2003) Deaths in Construction Related to Personnel Lifts, 1992-1999. Journal of Safety Research, 34, 507-514. https://doi.org/10.1016/j.jsr.2003.07.001

[36] Edmonds, G.A. and Miles, D.W.J. (1984) Foundations for Change: Aspects of the Construction Industry in Developing Countries. Intermediate Technology Publications Ltd., London. https://doi.org/10.3362/9781780442242.000

[37] Tetteh, S.N. (2003) Occupational Health and Safety Policy and Legislation in Ghana-Stakeholders' Workshop Report. African Newsletter on Occupational Health and Safety, 13, 19-21.

[38] Jacobzone, S., Choi, C. and Miguet, C. (2007) Indicators of Regulatory Management Systems. OECD Working Papers on Public Governance, 2007/4, OECD Publishing, Paris. https://doi.org/10.1787/112082475604

[39] Coglianese, C. (2012) Measuring Regulatory Performance: Evaluating the Impact of Regulation and Regulatory Policy. OECD Working Papers, 2012/1, OECD Publishing, Paris. https://www.oecd.org/gov/regulatory-policy/1_coglianese\%20web.pdf

[40] Antwi, S.K. and Hamza, K. (2015) Qualitative and Quantitative Research Paradigms in Business Research: A Philosophical Reflection. European Journal of Business and Management, 7, 217-225.

[41] Carson, D., Gilmore, A., Perry, C. and Gronhaug, K. (2001) Qualitative Marketing Research. Sage Publications, London. https://doi.org/10.4135/9781849209625

[42] Hirschman, E.C. (1985) Primitive Aspects of Consumption in Modem American Society. Journal of Consumer Research, 12, 142-154. https://doi.org/10.1086/208503

[43] Berger, P.L. and Luckman, T. (1967) The Social Construction of Reality. A Treatise in the Sociology of Knowledge. Penguin Group, London.

[44] Hudson, L. and Ozanne, J. (1988) Alternative Ways of Seeking Knowledge in Consumer Research. Journal of Consumer Research, 14, 508-521. https://doi.org/10.1086/209132

[45] Barriball, K. and While, A. (1994) Collecting Data Using a Semi-Structured Interview: A Discussion Paper. Journal of Advanced Nursing, 19, 328-335.

https://doi.org/10.1111/j.1365-2648.1994.tb01088.x 
[46] Sandelowski, M. (2008) Theoretical Saturation. In: Given, L.M., Ed., The SAGE Encyclopedia of Qualitative Research Methods, 2nd Edition, Sage, Thousand Oaks, 875-876.

[47] Saunders, B., Sim, J., Kingstone, T., Baker, S., Waterfield, J., Bartlam, B., Burroughs, H. and Jinks, C. (2018) Saturation in Qualitative Research: Exploring Its Conceptualization and Operationalization. Quality \& Quantity, 52, 1893-1907. https://doi.org/10.1007/s11135-017-0574-8

[48] Pope, C., Ziebland, S. and Mays, N. (2000) Qualitative Research in Health Care: Analysing Qualitative Data. British Medical Journal, 320, 114-116. https://doi.org/10.1136/bmj.320.7227.114

[49] Bryman, A. and Burgess, R. (1993) Analysing Qualitative Data. Routledge, London.

[50] Srivastava, A. and Thomson, S.B. (2009) Framework Analysis: A Qualitative Methodology for Applied Policy Research. Journal of Administration and Governance, 4, 72-79.

[51] Ritchie, J. and Spencer, L. (1994) Qualitative Data Analysis for Applied Policy Research. In: Bryman, A. and Burgess, R.G., Eds., Analyzing Qualitative Data, Routledge, Abingdon-on-Thames, 173-194. https://doi.org/10.4324/9780203413081_chapter_9

[52] Baldock, R., Vickers, I., Smallbone, D. and James, P. (2005) Health and Safety in Small Firms: What Are the Main Influences on the Adoption of Improvement Measures? MUBS Discussion Papers.

[53] Wright, M.S. (1998) Factors Motivating Proactive Health and Safety Management. Contract Research Report No. 179/1998, Health and Safety Executive. http://www.hse.gov.uk/research/crr_pdf/1998/CRR98179.pdf

[54] Leamon, T.B. (2001) The Future of Occupational Safety and Health. International Journal of Occupational Safety and Ergonomics, 7, 403-408. https://doi.org/10.1080/10803548.2001.11076510

[55] Jaselskis, E.J. anderson, S.D. and Russell, J.S. (1996) Strategies for Achieving Excellence in Construction Safety Performance. Journal of Construction Engineering and Management, 122, 245-255. https://doi.org/10.1061/(ASCE)0733-9364(1996)122:1(61)

[56] Gallagher, C. (1997) Occupational Health and Safety Management Systems: An Analysis of System Types and Effectiveness. Monash University, National Key Centre in Industrial Relations.

[57] Gad, S. and Collins, A.M. (2002) Safety Culture; a Review of the Literature Health and Safety Laboratory, London.

[58] Hinze, J. and Gambatese, J. (2003) Factors Influencing Safety Performance of Specialty Contractors. Journal of Construction Engineering and Management, 129, 159-164. https://doi.org/10.1061/(ASCE)0733-9364(2003)129:2(159)

[59] Cheng, C.-W., Leu, S.-S., Lin, C.-C. and Fan, C. (2010) Characteristic Analysis of Occupational Accidents at Small Construction Enterprises. Safety Science, 48, 698-707. https://doi.org/10.1016/j.ssci.2010.02.001 
Appendix 1: Relevant Requirements of OHS Laws in Ghana

\begin{tabular}{lc} 
Relevant requirement & $\begin{array}{c}\text { Clauses and/or } \\
\text { subclauses }\end{array}$ Remarks \\
\hline
\end{tabular}

Factories, Offices and Shops Act 1970 administered by Factories Inspectorate Department (FID)

Register construction site with FID

$6-8$

Report workplace accidents to FID

$6-8$

Provide wholesome drinking water on site

Provide toilet facilities on site

Provide personal protective equipment for workers

Take preventive measures to control or prevent specific hazards on sites $26,27 \& 31$ eg noise, vibration, manual handling, and fire.

Supervision of the health of employees where necessary.

Ensure safe access and egress to construction site.

Ensure the design and construction of structures should ensure workers 33 - 35 safety and users of the facility.

The provision of fencing and safeguards for the safety of workers on $\quad 38-40$ site.

Keeping records of lifting machines and appliances on site and ensuring 31, 43 - 47 they are of sound construction, properly maintained and precautionary measures taken during their operation.

Take precautionary measures to prevent injury and explosions because 48 - 49 of dust, gas, vapour present in work environment.

Ensuring steam boilers, receivers and containers and air receivers are of 50 sound construction, properly maintained and precautionary measures taken to ensure their operation.

Providing training for machine operators and persons employed in $\quad 36$ processes likely to cause injury.

Ensuring workers work under satisfactory, safe and healthy conditions 118(1)

Provide and maintain at site, plant and system of work that are safe and 118(2)(a) without risk to health.

Ensuring safety and absence of risks to health in connection with use, 118(2)(b) handling, storage and transport of materials.

Provide training, instruction, information and supervision to ensure health and safety at work.

Take steps to prevent contamination of the site by, and protect workers $118(2)(d)$ from toxic gases, noxious substances, vapours, dust fumes mists and other substances.

Provide at no cost to workers Personal protective equipment.

Provide suitable washing facilities and toilets and other facilities for cleansing and drying.

Provide clean and adequate drinking water on site.

Prevent occupational accidents and injury by minimizing the causes of hazards on site.

$118(2)(\mathrm{h})$ 


\section{Continued}

Workers reporting situations at site which they believe prevents an

119(1)

imminent and serious danger to life, safety or health.

Report occupational accidents and diseases to appropriate government agencies.

Workmen's Compensation Law, 1987

Payment of compensations due to injury arising out and in the course of employment (project execution).

Payment of medical expenses to workers or dependents in respect of injuries arising out and in the course of employment.

Payment of compensation in the event of incapacity death caused by diseases due to the nature of employment.

*The import of the clause is for contractor to indemnify the client against compensation claims. Compensation issues are dealt with in contract clauses through insurance. 